\title{
MAGNA CARTA AND ACCESS TO JUSTICE IN FAMILY PROCEEDINGS*
}

\author{
The Hon Mr Justice Mostyn ${ }^{\#}$
}

\section{INTRODUCTION}

We had a surprise in January 2012 when a practising QC was parachuted straight into the Supreme Court (as the Judicial Committee of the House of Lords became in 2009). But if there were expressions of discontent they were definitely sub rosa since the man in question, Jonathan Sumption QC, was then, and has since proved himself to be, preeminently qualified for the position. He is one of our foremost medieval historians, a Fellow of Magdalen College who taught History, before leaving to pursue a career at the Bar, where he rose to dizzy heights. His as yet uncompleted history of the Hundred Years' War has received the highest praise. So it perhaps was not surprising that in this octocentenial year he should have been asked by the Friends of the British Library (an audience I warrant as challenging as this) to speak to them about Magna Carta on 9 March 2015. If I may say so, his address "Magna Carta then and now" is a masterpiece. It completes the destruction of the hermeneutical myth originated by Sir Edward Coke which had been commenced by William McKechnie in his landmark essay published in 1905.

In his speech Lord Sumption began by saying:

"It is impossible to say anything new about Magna Carta, unless you say something mad. In fact, even if you say something mad, the likelihood is that it will have been said before, probably quite recently."

* Lecture delivered to the National Access to Justice and Pro Bono Conference, Sydney 18-19 June 2015.

\# The Hon Mr Justice Mostyn, Judge of the High Court of Justice, Family Division.

${ }^{1}$ Lord Sumption, 'Magna Carta Then and Now' (Supreme Court, 9 March 2015) <www.supremecourt.uk/docs/speech-150309.pdf> accessed 26 August 2015. 


\section{MAGNA CARTA AND ACCESS TO JUSTICE IN FAMILY PROCEEDINGS}

I will not presume to say anything new about Magna Carta. In fact my principal subject matter - the withdrawal of legal aid from private law family cases - has nothing to do with Magna Carta except in the extended mythic sense with which Sir Edward Coke and others have since clothed it. Indeed I am supremely unqualified to talk about it. Until comparatively recently my knowledge of it was confined to my childhood reading. At age six I read the Nursery History of England ${ }^{2}$ which told me that:

\section{“THE SIGNING OF THE GREAT CHARTER}

At last all the people in the country were so angry with John that the chief men-said they would fight against him if he did not promise to do better. The new archbishop, Stephen Langton, was very anxious to make the king better to his people. At last they wrote down a great many promises, and they made John say he would keep them, and he had to put a mark under the writing to show that it was a solemn promise.

King John never meant to keep his promises, and after he had signed the "Great Charter," as the writing was called, he threw himself upon the ground and kicked and groaned in anger. He died soon afterwards."

At age 10 I read (and have regularly re-read) that magnificent piece of nonsense 1066 And All That. ${ }^{3}$ This is what it told me:

"the Barons compelled John to sign the Magna Charter, which said:

1. That no one was to be put to death, save for some reason (except the Common People).

2. That everyone should be free - (except the Common People).

3. That everything should be of the same weight and measure throughout the Realm - (except the Common People).

\footnotetext{
2 Elizabeth O'Neill, Nursery History of England (TC and EC Jack Ltd 1877).

${ }^{3}$ W Sellar and R Yeatman, 1066 And All That (Methuen and Co 1930).
} 
4. That the Courts should be stationary, instead of following a very tiresome medieval official known as the King's Person all over the country.

5. That "no person should be fined to his utter ruin" - (except the King's Person).

6. That the Barons should not be tried except by a special jury of other Barons who would understand.

Magna Charter was therefore the chief cause of Democracy in England, and thus a Good Thing for everyone (except the Common People).

After this King John hadn't a leg to stand on and was therefore known as 'John Lackshanks."'

As we will see, this was a remarkably perceptive analysis of the Charter. The authors had earlier referred to Pope Innocent III thus:

"John was so bad that the Pope decided to put the whole country under an Interdict, i.e. he gave orders that no one was to be born or die or marry (except in Church porches). But John was still not cured of his Badness; so the Pope sent a Bull to England to excommunicate John himself. In spite of the King's efforts to prevent it the Bull succeeded in landing and gave orders that John himself was not to be born or marry or die (except in Church porches); that no one was to obey him or stand him a drink or tell him the right time or the answer to the Irish Question or anything nice. So at last John gave way and he and his subjects began once more to be born and to marry and to die, etc. etc."

And we all know that this same Bullish Pope annulled the Charter within 10 weeks of John sealing it. He denounced it as "not only shameful and base but illegal and unjust".

For the purposes of this address I have consulted a number of sources. Among many others I have read Sir Matthew Hale's History of the Common Law of England (published posthumously in 1716 - he died in 1676); Sir William Blackstone's Commentaries on the Laws of England (12th edition, 1795 - he died in 1780); and Sir William Holdsworth's $A$ History of English Law (3rd edition 1922) to see what past commentators, other than the hierarch Sir Edward Coke, had to say about the Charter. 


\title{
MAGNA CARTA AND ACCESS TO JUSTICE IN FAMILY PROCEEDINGS
}

For Hale the only true source of law was that made by the judges, the common law. He seemed to regard Royal Charters or Acts of Parliament as little better than distractions from the true development of the law at the hands and minds of the judges. And who am I to criticise that? Inasmuch as praise was to be bestowed on John's royal laws, Hale seems more impressed by what he described as laws which allowed "Mulcts [to be] imposed for barbarous and disorderly Pleading" he observing that at that time "Proceedings in his courts were rude, imperfect and defective to what they were in the ensuing time of Edward I". However, he did go this far:

\begin{abstract}
"But the Great Charter, and the Charter of the Forest, did not expire so; for in 1253, they were again sealed and published: And because after the Battle of Evesham, the King had wholly subdued the Barons, and thereby a Jealousie might grow, that he again meant to infringe it; in the Parliament at Marlbridge they are again confirm'd. And thus we have the great Settlement of the Laws and Liberties of the Kingdom established in this King's time (he means Henry III): the Charters themselves are not every Word the same with those of King John, but they differ very little in Substance.
\end{abstract}

This Great Charter and the Charta de Foresta was the great Basis upon which this Settlement of the English laws stood in this King and his Son; there were also additional Laws of this King yet extant which much polished the Common Law viz The Statutes of Merton and Marlbridge, and some others."

Blackstone acknowledges that the first source of the absolute rights of every Englishman is "the great charter of liberties, which was obtained, sword in hand, from King John, and afterwards, with some alterations, confirmed in Parliament by King Henry III his son." However, he goes on to say:

"Which charter contained very few new grants; but as Sir Edward Coke observes, was for the most part declaratory of the principal grounds of the fundamental laws of England."

As far as Blackstone was concerned the real hero in the promulgation and securing of these rights was Edward I, who he wrote "hath justly been stiled our English Justinian". He passed a statute in 1297 (25 Edw I, c1) entitled "Confirmatio Cartarum de Libertatibus Angliae et Forest" which stated that "the great charter is directed to be allowed as the common law; 
all judgments contrary to it are declared void; copies of it are to be sent to all cathedral churches, and read twice a year to the people....". It threatened excommunication to those who denounced it. ${ }^{4}$ His grandson Edward III went further and in his reign in 1369 Parliament (which had arrived as a recognisable body in 1258 - the earliest Statute Roll begins in 1278 and the earliest Parliamentary Roll is of the year 1290) passed a statute that rendered void any statute which infringed its provisions (42 Edw III, c1). It stated: "that the great Charter and the Charter of the Forest be holden and kept in all points; and that if there be any Statute made to the contrary, it shall be holden for none". Which was perhaps the nearest we ever got to an entrenched constitution.

At all events the Charter was confirmed and reissued by Henry III in 1225 in a revised form (9 Hen III), and, as we have seen, entered the Statute Roll in 1297 (25 Edw I, c1). ${ }^{5}$ And of this sections 1 (Confirmation of Liberties), 9 (Liberties of London, \&c), and 29 (Imprisonment \&c contrary to Law. Administration of Justice) remain in force. (This latter clause, the most famous of all, was divided between the thirty-ninth and fortieth clauses in the version sealed by John). In all it was confirmed some thirty times in the Middle Ages.

You will have noticed my references to the parallel Charter of the Forest. ${ }^{6}$ This mitigated and regulated the laws concerning hunting in the forest. Blackstone explained the context:

"Richard the first, a brave and magnanimous prince, was a sportsman as well as a soldier; and therefore enforced the forest

\footnotetext{
${ }^{4}$ Henry III in 1253 threatened excommunication against all who took even the humblest part in infringing or altering its clauses: clam vel palam facto, verbo, vel consilio.

${ }^{5}$ The original of this copy of the Charter hangs in Parliament House in Canberra. The mother of a friend of mine found another 1297 copy in her attic at Deene Park in Northamptonshire in the 1970s. They had no idea how it got there. It appears to have been at Deene Park from at least the early 1600s. Only 17 copies of the charter from the 13th century are known to survive; the Brudenells' example was the only one in private hands, and one of only five still carrying a royal seal. In 1983 it was sold privately to Ross Perot. It was sold again in December 2007 for more than US\$21 million, and is on display in the National Archives in Washington, DC, alongside the Declaration of Independence and the United States Constitution: see 'Marian Brudenell' (The Telegraph, 6 September 2013) <www.telegraph.co.uk/news/obituaries/10292398/Marian-Brudenell.html> accessed 26 August 2015.

${ }^{6}$ This was originally part of the Charter sealed in 1215 but was separated out into its own berth in 1217 after the death of John in 1216.
} 


\section{MAGNA CARTA AND ACCESS TO JUSTICE IN FAMILY PROCEEDINGS}

laws with some vigour; which occasioned many discontents among his people, though he repealed the penalties of castration, loss of eyes, and cutting off of hands and feet, before inflicted on such as transgressed, in hunting; probably finding that their severity prevented prosecutions."

I have not researched what the new penalties were but I suspect they were more severe than those prescribed in the Hunting Act 2004 (which banned the hunting of (some but not all) mammals with (more than two) "dogs" (but not by any other means)). ${ }^{7}$

Holdsworth supplies some fascinating historical context. He bases many of his views on McKechnie's essay, which is, plainly a, if not the, prime source for students of the Charter. He explains how this particular charter of liberties can be traced back, through the charters of liberties granted by Henry II, Stephen and Henry I on their coronations, to King Cnut's charter of liberties. Cnut's charter is the direct linear ancestor of Magna Carta. So Magna Carta was not brand new; and was certainly not the bombshell that the later myth-makers have made it out to be. However, it did mark a watershed, at least up to a point. Holdsworth's view was this:

"though, therefore, we can trace its form back to Anglo-Saxon times, though we can trace the genesis of some of its clauses to that charter of Henry I which Stephen Langton brought to the notice of the barons as a precedent for the demands which they were about to make upon the king, the Great Charter differs fundamentally from any preceding charter in the manner in which it was secured, in its contents, and in its historical importance. It was secured by a combination of the landowners, the church, and the merchants; and therefore it contained clauses dealing specifically with their particular grievances. Since the time when the charter of Henry I had been issued, a centralized administrative and judicial system had been created and elaborated. The Charter therefore necessarily contained many clauses which related to the working of that system. The granting of the Charter, and the success of the barons in maintaining it, opened a new chapter in

\footnotetext{
${ }^{7}$ In order to force through this vitally important piece of legislation the Blair Government required Parliament to spend over 700 hours debating the issue (more than 10 times it spent discussing the Iraq war) and had to invoke the Parliament Acts 1911 and 1949 to override the House of Lords for only the fourth time since 1949.
} 


\section{THE DENNING LAW JOURNAL}

English history, which ended by establishing a system of constitutional government, of which the Charter was regarded as the pledge and the symbol."

Lord Bingham, in his essay Magna Carta $^{8}$ goes even further in the direction of the hagiographers. He writes:

"Conditioned as we are today by our own knowledge of political and constitutional development over the last nine centuries, it calls for the exercise of real historical imagination to appreciate the enormity, the grandeur of what was done at Runnymede. King John entered the meadow as a ruler acknowledging no secular superior, whose word was law. He left the meadow as a ruler who had acknowledged, in the most solemn manner imaginable, that there were some things even he could not do, at any rate without breaking his promise. This, then, is the enduring legacy of Magna Carta: the lesson that no power is absolute; that all power, however elevated, is subject to constraint; that, as was to be said by Dr Thomas Fuller some centuries later, 'Be you never so high, the law is above you'."

Needless to say, Lord Sumption douses these views with cold water. He explains pitilessly that it is not true that Magna Carta was the origin of the principle of the rule of law. The English Kings had broken the law quite frequently before Magna Carta, and they continued to break it afterwards. But the idea that the King was subject to law had for a very long time been part of the orthodoxy of medieval constitutional thought both in England and elsewhere. The barons did not invent it at Runnymede. Their object was to define what the law was. No one doubted that whatever it was, the King was subject to it.

One thing is certain. The Charter did not benefit the common people one whit, and Sellar and Yeatman were quite right when they wrote their amusement in 1930. Although Coke attempted to argue that the famous clause 39 extended to all people it is clear that this was not so. ${ }^{9}$ As Holdsworth explains:

\footnotetext{
${ }^{8}$ Tom Bingham, Lives of the Law (OUP 2011).

${ }^{9}$ Blackstone also commits the same solecism writing that "it protected every individual of the nation in the free enjoyment of his life, his liberty, and his property, unless declared to be forfeited by the judgment of his peers or the law of the land". In a footnote he references chapter 29 of the Charter which is of course not the same as clause 39 of the version sealed by John (q.v.).
} 


\section{MAGNA CARTA AND ACCESS TO JUSTICE IN FAMILY PROCEEDINGS}

"It does not legislate for Englishmen generally, but attempts to safeguard the rights of different classes according to their different needs. Churchmen, lords, tenants, and merchants are separately provided for. But there are some clauses of the Charter, notably the famous section 39, in which rights are conferred upon all 'liberi homines.' The phrase liberi homines is clearly not confined to tenants in chief; but did it include the villeins, or were they excluded from the benefits conferred? ... It is fairly certain that they were not considered to be thus included in 1215. It is true that they seem to be provided for in section 20 , which provides that a villein shall be amerced 'saving his contenement and his wainage.' But it is fairly clear that they were thus protected, not because it was intended to confer any rights upon them, but because they were the property of their lords, and excessive amercements would diminish their value. When the Charter was reissued in 1216, this intention was made quite clear by a slight alteration in wording. It was provided that a villein other than the king's villein was not to be thus amerced. Thus, although the Charter was comprehensive in its scope it did not embrace all Englishmen."

In her excellent speech in 2011 entitled "Equal Access to Justice in the Big Society" Lady Hale put it more pithily: "I doubt whether the medieval barons gave any thought to the poor and vulnerable in their society, still less to the women".

It was not until the statute of Edward III in 1331 (5 Edw III, c9) that clause 39 of the 1215 version (clause 29 of the version of 1225) was extended to all men whatever their status. And it was not until 1354 (28 Edw III, c3) that "due process" 10 was formally extended to all men. Whatever Magna Carta was, it was not a Universal Declaration of Human Rights.

Clause 40 of the 1215 Charter famously provides that "we will sell to no man, we will not deny or defer to any man either Justice or Right". ${ }^{11}$ Again, as Lord Sumption explains, the notion that the proscription on "selling" justice means that the state is obliged to provide free justice is

\footnotetext{
10 "No Man, of what Estate or Condition that he be, shall be put out of Land or Tenement, nor taken, nor imprisoned, nor disinherited, nor be put to Death, without being brought in Answer by due Process of Law". So far as I can tell this is the origin of the mystical phrase "due process of law". The original Norman French is "saunz estre mesne en respons par due proces de lei".

${ }^{11}$ Now part of clause 29 of the 1225 Charter in force.
} 
much misunderstood. At the time the King had a personal judicial jurisdiction over his "tenants-in-chief", essentially the baronage and the richer knights. He had a habit of adjudicating disputes personally rather than delegating them to his justices. And he demanded large sums, known as "proffers", for access to his court. This is what clause 40 was aimed at. For run-of-the-mill litigants access to the general courts required payment of fees for writs and subpoenas. Clause 40 did not affect these fees one jot.

In 1495, during the reign of Henry VII, Parliament passed a statute (11 Hen 7, c12) "to admit such persons as are poor to sue in Forma Pauperis". ${ }^{12}$ This provided that every poor person might issue "Writ or Writs Original and Writs of Subpoena ... nothing paying to your Highness for the Seals of the same, nor to any Person for the writing of the same" and that the Justices "shall assign to the same poor Person ... Counsel learned, by their Discretions, which shall give their Counsels, taking nothing for the same". ${ }^{13}$ It might be thought that here lies the origin of legal aid in England and Wales, but again, that would be wrong, for, as Tindall CJ pointed out in Brunt v. Wardle: ${ }^{14}$

"But, after all, is the 11 Hen 7, c12, any thing more than confirmatory of the common law? In the learned report of the Serjeants' case by my brother Manning, p. 41, note (d), a case is referred to that occurred in the $15 \mathrm{Ed}$. 4, twenty years before the passing of that act, from which it appears that at common law if a party would swear that he could not pay for entering his pleadings, the officer was bound to enter them gratis; and that in this court there was a presignator pur les poers."

So, the common law had, at the latest by 1475 in the reign of Edward $\mathrm{IV}$, in the midst of the War of the Roses, invented a procedure of relief from court fees and costs. Of course, this had nothing to do with Magna

\footnotetext{
12 This statute was cited in the Supreme Court of Canada by McLachlin CJ in Trial Lawyers Association of British Columbia v. British Columbia (Attorney General) [2014] SCC 59 [48] where she referred to the "long tradition in the common law of providing exemptions for classes of people who might be prevented from accessing the courts - a tradition that goes back to the Statute of Henry VII".

${ }^{13}$ A statute had been passed in Scotland in 1424 which provided for free legal assistance for "poor creatures" who could not pay costs on account of "default of cunning or means".

14 (1841) 3 Man. \& G. 534.
} 


\section{MAGNA CARTA AND ACCESS TO JUSTICE IN FAMILY PROCEEDINGS}

Carta. It appears that the liability of the loser to pay the costs of the winner did not arise until 1531, during the reign of Henry VIII, when Parliament passed a statute intituled "An Act that the Defendant shall recover costs against the Plaintiff, if the Plaintiff be nonsuited, or if the Verdict pass against him". This initially limited the power to make an order for costs to certain specific suits but was extended in the reign of James I (4 Jac I, c3) to "any Action whatsoever". In her excellent speech Lady Hale stated:

"A statute of Henry VIII in 1531 even provided that they should be relieved of having to pay the other side's costs if they lost - but they had to suffer some other punishment instead, such as being whipped or pilloried."

In fact the statute did not say that, but rather that they "shall suffer other Punishment, as by the Discretion of the Judge or Justices, afore whom such suits shall depend, shall be thought reasonable", and I can find no evidence that whipping or pillorying was ordered against unsuccessful pauper litigants, however reasonable that might have been then (or even now).

Holdsworth and Lord Sumption ruthlessly hunt down and put to death a number of other persistent and obstinate canards. Sir Edward Coke suggested that clauses 39 and 40 embodied the principles of habeas corpus and trial by jury. As Holdsworth says "It is not difficult to show that taken literally, these interpretations are false. Trial by jury was as yet in its infancy. The writ of Habeas Corpus was not yet invented; and as we shall see, it was long after it was invented that is was applied to protect the liberty of the subject."

It is noteworthy that as time passed and the Middle Ages evolved into the Renaissance, and with the stability and national independence provided by the Tudor regime following the defeat of (the recently reburied) Richard III at Bosworth in 1485, Magna Carta receded from public and legal consciousness, almost into oblivion. By the time of reign of Elizabeth I, Gloriana, it had almost disappeared from view, so much so that when Shakespeare, her chief propagandist, wrote King John in 1596, five years before her death, he did not mention it, or the events surrounding it, at all. ${ }^{15}$ On the contrary the whole play concerns the dispute about the right to the crown between King John and France's Philip II (and later his son Louis VIII "the lion") who supported John's nephew Arthur. The nearest one gets to baronial disaffection is where they

${ }^{15}$ Inevitably, this is being performed today at the Globe Theatre in London. 
support Louis (for a while) when he mounts a (now almost totally forgotten) invasion. They later revert to their true loyalties; Louis is seen off; John is poisoned by a treacherous monk; and on his death-bed his nobles gather around him. Dr Goebbels would have been proud of this falsification of history. The principal themes of the play were the familiar fare dished out to the groundlings at that time: that the French are bad, and Catholic monks are worse; and English Kings, even if enduring a "troublesome reign", are top dogs and the real thing (provided they were not Plantagenets like Richard III).

Lord Sumption explains that Coke's elevation of Magna Carta into a sacred, numinous, text only arose after his dismissal by James I in 1616 as Chief Justice of the King's Bench as a result of his protests against the King's interference with the workings of the courts. ${ }^{16}$ In his retirement he transformed it "from a somewhat technical catalogue of feudal regulations, into the foundation document of the English constitution, a status which it has enjoyed ever since among the large community of commentators who have never actually read it." ${ }^{, 17}$ For this the Americans bear a heavy responsibility. They adored Magna Carta and relied on it in spades to justify their rebellion against the government of George III. Its very language is incorporated into the constitutions of about 30 of the individual states.

But when he held office even Coke did not reach for Magna Carta when making his momentous decisions. One of the most famous is the Proclamations' Case. ${ }^{18}$ Coke, then Chief Justice of the Common Pleas was asked by the Lord Chancellor and the Lord Treasurer whether King James I could by mere proclamation prohibit new buildings in London (an early town and country planning measure?) or the making of starch from wheat (food standards?). After consulting the Chief Justice of the King's Bench and the Chief Baron of the Exchequer Coke held:

\footnotetext{
${ }^{16}$ Following his dismissal in 1616 Coke re-entered politics and was returned as MP for Liskeard in 1620. On 11 December 1621 Parliament issued a Remonstrance to the King authored by Coke, in which they restated their liberties and right to discuss matters of state. James retaliated by dissolving Parliament and imprisoning Coke in the Tower for 9 months. He died in 1634.

${ }^{17}$ It is worth reflecting on the various things that Magna Carta regulated. For example, widows were not to be forced to remarry, although if they did they needed to ask the King's or their lord's consent. All fishweirs were to be removed from the Thames and elsewhere. No-one was to be forced to build bridges across rivers. Alien knights and crossbowmen were to be sent home. All forests which had been afforested in John's reign were to be deforested. See I Judge and A Arlidge, Magna Carta Uncovered (Hart Publishing 2014).

18 (1611) 12 Co Rep 74; 2 State Tr 723.
} 


\section{MAGNA CARTA AND ACCESS TO JUSTICE IN FAMILY PROCEEDINGS}

"the King by his proclamation cannot create any offence which was not an offence before, for then he may alter the law of the land by his proclamation in a high point; for if he may create an offence where none is, upon that ensues fine and imprisonment: also the law of England is divided into three parts, common law, statute law, and custom; but the King's proclamation is none of them: also malum aut est malum in se, aut prohibitum, that which is against common law is malum in se, malum prohibitum is such an offence as is prohibited by Act of Parliament, and not by proclamation. Also it was resolved, that the King hath no prerogative, but that which the law of the land allows him."

No mention of Magna Carta there.

In citing this case in the appeal in Council of Civil Service Unions and Others $v$ Minister for the Civil Service ${ }^{19}$ (the GCHQ case) Lord Fraser stated that "the royal prerogative has always been regarded as part of the common law ... and subject to the common law". No mention there of Magna Carta either.

In the earlier case of Prohibitions Del Roy ${ }^{20}$ James I (supported by the Archbishop of Canterbury) had claimed to possess the power to determine issues of law in Ecclesiastical causes: "the King himself may decide it in his Royal person; and that the Judges are but the delegates of the King, and that the King may take what causes he shall please to determine, from the determination of the Judges, and may determine them himself." The Archbishop said "that this was clear in divinity, that such authority belongs to the King by the word of God in the Scripture."

Coke was having none of it. He held that "the King in his own person cannot adjudge any case, either criminal or betwixt party and party; but it ought to be determined and adjudged in some Court of Justice, according to the law and custom of England. The King may sit in the King's Bench, but the Court gives the judgment. No King after the conquest assumed to himself to give any judgment in any cause whatsoever which concerned the administration of justice, within the realm; but these causes were solely determined in the Courts of Justice. The King cannot arrest any man." And he ended his judgment by citing Henry de Bracton: Rex non debet esse sub homine, sed sub Deo et lege. Again, no mention of Magna Carta there.

\footnotetext{
${ }^{19}$ [1985] AC 374.

20 (1607) 12 Co Rep 63.
} 
So, we see what Magna Carta does not furnish. It does not newly restrain the power of the monarch. It does not establish separation of powers. It does not create a representative Parliament. It does not invent trial by jury. It does not create habeas corpus. It does not provide a forerunner for legal aid (which was not in fact invented in the UK in its current form until 1949). In a withering passage Lord Sumption derides David Cameron who "armed with a copy of an Edwardian illustrated textbook for children, has called it the document that paved the way for democracy, equality and the rule of law, the "foundation of all our laws and liberties"". This sort of claim is, he says, "high-minded tosh...the worst kind of ahistorical Whiggism".

Lord Sumption ends his paper by asking and answering these two questions which reflect his status as a historian of rigour:

"so when we commemorate Magna Carta, perhaps the first question that we should ask ourselves is this: do we really need the force of myth to sustain our belief in democracy? Do we need to derive our belief in democracy and the rule of law from a group of muscular conservative millionaires from the north of England, who thought in French, knew no Latin or English, and died more than three quarters of a millennium ago? I rather hope not."

But plainly Magna Carta does represent something. Lord Sumption's view is this:

"Yet Magna Carta matters, if not for the reasons commonly put forward. Some documents are less important for what they say than for what people wrongly think that they say. Some legislation has a symbolic significance quite distinct from any principle which it actually enacts. Thus it is with Magna Carta. It has become part of the rhetoric of a libertarian tradition based on the rule of law that represents a precocious and distinctively English contribution to western political theory. The point is that we have to stop thinking about it just as a medieval document. It is really a chapter in the constitutional history of seventeenth century England and eighteenth century America."

And, indeed, Australia also.

Holdsworth also sees it as a milestone on the road to freedom. He says that "the historian may prove that there is no strict agnatic relationship [between trial by jury or the writ of habeas corpus and Magna Carta]; he must admit that there is a natural - a cognatic - link". Blackstone too sees 


\section{MAGNA CARTA AND ACCESS TO JUSTICE IN FAMILY PROCEEDINGS}

it as important but not necessarily as the second coming. For him there is a steady progression in the promulgation of just laws, the administration of justice, and the relationship between the rulers and the ruled. He charts a progress from Henry I and the creation of the grand assize and itinerant justices of eyre travelling out on circuit to hear cases; to Magna Carta; to the summoning of knights, citizens and burgesses to Parliament in the reign of Henry III; to the massive programme of law reform instituted by Edward I (including reform of the laws of King Alfred for preserving the public peace and preventing robberies). For him "the very scheme and model of the administration of common justice between party and party, was entirely settled by this King; and has continued nearly the same, in all succeeding ages, to this day; abating some few alterations, which the humour or necessity of subsequent times has occasioned" and "more was done in the first thirteen years of his reign to settle and establish the distributive justice of the kingdom, than in all the ages since that time put together". He then marks a "long interval" until the Petition of Right, assented to by Charles I; the Habeas Corpus Act, passed under Charles II in 1679 (31 Cha 2, c2) (new style dating, ${ }^{21}$ as will be all dates hereafter); and the Declaration of Rights presented to the Prince and Princess of Orange in February 1689 and enacted in December of that year as the Bill of Rights following the Glorious Revolution (1 Gul \& Mar Sess 2 c2).

Ironically, the myth took firm hold in the minds of the common people, from whom the benefits of the Charter were withheld by design for over 100 years. In the famous meditation on the rule of law at the end of "Whigs and Hunters",2 (his well known book about the Black Act of 1723 (9 Geo 1, c22)) the polemical historian, socialist and peacenik E.P. Thompson wrote:

"turn where you will, the rhetoric of eighteenth century England is
saturated with law. Royal absolutism was placed behind a high
hedge of law ... And the rulers were, in serious senses, whether
willingly or unwillingly, the prisoners of their own rhetoric; they

${ }^{21}$ The Calendar (New Style) Act 1750 (otherwise Chesterfield's Act) not only adopted the Gregorian calendar (and thus abolished the dates 3 - 13 September 1752) but also fixed the start day of the year as 1 January rather than Lady Day (25 March). Thus the Habeas Corpus Act 1679, which was passed between 6 and 25 March, is dated 1678 in the Statutes at Large. The 1750 Act also means that the correct date for the octocentenary, in terms of exact circumsolar orbits, is 26 June 2015 not 15 June 2015.

${ }^{22}$ Edward Thompson, Whigs and Hunters (Allen Lane 1975) 263-264; (Breviary Stuff Publications 2013) 206, 208. 
played the games of power according to rules that suited them, but they could not break those rules or the whole game would be thrown away. And, finally, so far from the ruled shrugging off this rhetoric as a hypocrisy, some part of it at least was taken over as part of the rhetoric of the plebeian crowd, of the free-born Englishman with his inviolable privacy, his habeas corpus, his equality before the law. If this rhetoric was a mask, it was a mask which John Wilkes was to borrow, at the head of ten thousand masked supporters. ... If the rhetoric was a mask, it was a mask which Ghandi and Nehru were to borrow, at the head of a million masked supporters." 23

Magna Carta was referenced by the felon, agitator and minor poet John Grant who was sentenced to death, but at the last moment reprieved and transported for life to the penal colony of New South Wales in 1804, for shooting at a family solicitor who frustrated his attempts to woo the daughter of an aristocrat. ${ }^{24}$ In a (not very good) piece of verse he wrote:

"Ye Captains to a Monarch lov'd rever'd

Draw on his head and yours disgrace Down!

The 'Magna Charta' our forefather's rear'd

That brightest jewel in the British Crown

Ye trample on *! - Tho' Britons rule the Waves

Great George's subjects (Britons!) here are Slaves.

O country beauteous! Climate healthful! mild!

O George belov'd (Unlike some Kings) abus'd!

O People into Slavery beguil'd!

O Rulers guilty of a power misus'd

When shall All cry 'Britannia rules the Waves

And Free- born Britons are no longer Slaves'?"25

And so, recognising that Magna Carta is important, but not nearly as important as some commentators make out, but equally recognising it as

\footnotetext{
${ }^{23}$ But he did not mention Magna Carta in the book.

${ }^{24} \mathrm{He}$ was later pardoned by Macquarie and returned to England in 1811.

25 David Neal, The Rule of Law in a Penal Colony: Law and Politics in Early New South Wales (CUP 1990) 61.
} 


\section{MAGNA CARTA AND ACCESS TO JUSTICE IN FAMILY PROCEEDINGS}

the mythical fons et origo of the rhetoric of a libertarian evolution based on the rule of law I turn, at last, to the subject matter of this address. ${ }^{26}$

In Ashby $v$ White ${ }^{27}$ Ashby, a burgess of Aylesbury, was entitled under the borough charter to vote at parliamentary elections. White, a returning officer, maliciously refused to allow him to vote. Ashby thereupon sued White. Lord Chief Justice Holt (dissenting, but later vindicated by the House of Lords) said:

"If the plaintiff has a right he must of necessity have a means to vindicate and maintain it, and a remedy if he is injured in the exercise or enjoyment of it; and indeed it is a vain thing to imagine a right without a remedy for want of a right and want of remedy are reciprocal. ... My brother Powell indeed thinks that an action upon the case is not maintainable, because there is no hurt or damage to the plaintiff: but surely every injury imports a damage though it does not cost the party one farthing, and it is impossible to prove the contrary; for a damage is not merely pecuniary, but an injury imports a damage, when a man is thereby hindred of his right. As in an action for slanderous words, though a man does not lose a penny by reason of the speaking them, yet he shall have an action. So if a man gives another a cuff on the ear, though it cost him nothing, no not so much as a little diachylon, ${ }^{28}$ yet he shall have his action, for it is a personal injury ... But in the principal case my brother says, we cannot judge of this matter, because it is a Parliamentary thing. O! by all means be very tender of that. Besides it is intricate, and there may be contrariety of opinions." ${ }^{29}$

\footnotetext{
${ }^{26}$ Holdsworth says that "we may compare it to the Twelve Tables [of the Roman Republic]. In the same sense as they were regarded as the 'fons et origo juris civilis' Magna Carta is the fount and source of our constitutional law".

27 (1702) 2 Ld Raymond 938.

${ }^{28}$ An 18th C homeopathic medicine made of the juices of several plants (thus its name).

${ }^{29}$ This case roused intense feeling in the Commons, who imagined that the Courts were infringing their privileges. They caused Ashby and his counsel to be imprisoned, and when these sued out a writ of habeas corpus, they sent the Sergeant-at-Arms to arrest Lechmere (afterwards Attorney-General), who had acted in the habeas corpus proceedings. The officer reported that Lechmere had evaded him: "he got out of his chamber in the Temple, two pairs of stairs high, at the back window, by the help of his sheets and a rope". Queen Anne was forced to end the dispute by proroguing Parliament.
} 
A remedy can only mean a remedy granted by a court, and that entails meaningful access to the court. That right to access to justice has long been recognised by the common law (even if for centuries the costs of doing so have been prohibitive, and the delays intolerable ${ }^{30}$ ). In $R$ (Witham) $v$ Lord Chancellor Laws LJ stated: ${ }^{31}$

"...the common law provides no lesser protection of the right of access to the Queen's courts than might be vindicated in Strasbourg. ... Indeed, the right to a fair trial, which of necessity imports the right of access to the court, is as near to an absolute right as any which I can envisage."

His reference to Strasbourg was, of course to Article 6 of the European Convention on Human Rights (1950) which provides:

"In the determination of his civil rights and liabilities or of any criminal charge against him, everyone is entitled to a fair and public hearing within a reasonable time by an impartial tribunal established by law."

We have seen some early measures designed to alleviate the lot of indigent litigants seeking to exercise the right of access to the courts. There were further efforts by philanthropic organisations to provide "poor man's lawyers" during the 19th century but large areas of unmet need were left. It was not until the period of the Second World War (when Beveridge was beginning his work on the formation of the welfare state) that refugee scholars from Europe, with experience of Continental systems where better provision was made, began to make a compelling case for a comprehensive system of legal aid. In his outstanding book The Rule of Law, ${ }^{32}$ Lord Bingham cited Dr EJ Cohn's paper Legal Aid for the Poor: A study of Comparative Law and Legal Reform ${ }^{33}$ where he (Cohn) stated:

"Legal aid is a service which the modern state owes to its citizens as a matter of principle. . . Just as the modern State tries to protect the poorer classes against the common dangers of life, such

\footnotetext{
30 As to which see Dickens's accurate descriptions in Bleak House. When delivering his famous "to be or not to be" soliloquy Hamlet cited "the law's delay" as one of many good reasons for killing himself.

31 [1998] QB 575, 585-586 (Laws LJ).

${ }^{32}$ Tom Bingham, The Rule of Law (Allen Lane 2010) 87.

33 (1943) 59 LQR 250, 253.
} 


\section{MAGNA CARTA AND ACCESS TO JUSTICE IN FAMILY PROCEEDINGS}

as unemployment, disease, old age, social oppression, etc, so it should protect them when legal difficulties arise. Indeed the case for such protection is stronger than the case for any other form of protection. The State is not responsible for the outbreak of epidemics, for old age or economic crises. But the State is responsible for the law."

These and many other arguments were considered by Lord Rushcliffe's committee which reported in 1945, and led to the introduction of near universal civil legal aid by the Legal Aid and Advice Act 1949. It did not apply to defamation proceedings or to some peculiar archaic family proceedings, now long abolished (breach of promise; loss of services of a woman as a result of seduction; inducement of a spouse to leave another). But routine private family law proceedings, whether concerning divorce, money or children were within scope. From the start this entitlement was subject to means testing. Section 2 provided that it should be available to any person whose disposable income did not exceed $£ 400$ per annum (a very large sum then), but that it may be refused if the person had disposable capital of more than $£ 500$.

Legal aid has been described as the fourth pillar of the welfare state, the others being health, education and social security. Initially over $80 \%$ of the population satisfied the means test for civil legal aid; this fell progressively so that by 2007 only $27 \%$ did. The right to legal aid in private law family proceedings was preserved in the Legal Aid Act 1988 and in the Access to Justice Act 1999. In 2005 the state funded about 45,000 such cases at a cost of about $£ 130 \mathrm{~m}$.

I have mentioned above Art 6(1) of the European Convention on Human Rights. There have been decisions from the Strasbourg court which have interpreted that provision to say that in some complex, exceptional, cases this requires the grant of legal aid, even if no scheme exists for the matter in hand: see, for example, Airey $v$ Ireland $^{34}$ (no legal aid was available for judicial separation proceedings in the Republic of Ireland) and Steel and Morris v United Kingdom ${ }^{35}$ (the "McLibel" case, where no legal aid was available in the UK for defamation proceedings). In the latter case the Strasbourg Court found at para 72 that the denial of legal aid to the applicants deprived them of the opportunity to present their case effectively before the court and contributed to an unacceptable inequality of arms. The human right to legal aid has been taken further by the Charter of Fundamental Rights of the European Union (30 March

\footnotetext{
${ }^{34}$ (1979-80) 2 EHRR 305.

35 (2005) 41 EHRR 22.
} 
2010), which certainly applies in the UK where EU law is in play, and may well apply more generally. ${ }^{36}$ Art 47 provides:

\section{"Right to an effective remedy and to a fair trial}

Everyone whose rights and freedoms guaranteed by the law of the Union are violated has the right to an effective remedy before a tribunal in compliance with the conditions laid down in this Article.

Everyone is entitled to a fair and public hearing within a reasonable time by an independent and impartial tribunal previously established by law. Everyone shall have the possibility of being advised, defended and represented.

Legal aid shall be made available to those who lack sufficient resources in so far as such aid is necessary to ensure effective access to justice."

Unfortunately, the cost of the legal aid scheme was its undoing. By 1997 it was the fastest rising item of government expenditure. It was inevitable that following the crash of 2008 and with the election of the new austerity-driven coalition government in 2010 that serious curbs on the scheme would be imposed. What no-one anticipated was the savagery of the cuts, with private family law proceedings, save in certain very limited circumstances, being taken out of scope altogether.

In November 2010 the new coalition government published its consultation paper Proposals for the Reform of Legal Aid in England and Wales. In its foreword the then Lord Chancellor wrote of "achieving substantial savings" to reduce the fiscal deficit and to return the country's economy to stability and growth. In its body the government wrote about making "tough decisions about where best to target resources". It stated at para 4.67 its belief that "legal aid is not routinely justified for ancillary relief proceedings and private law family and children proceeding". In para 4.207 it stated:

"While we understand that those going through relationship breakdown may be dealing with a difficult situation, both emotionally and often practically too, we do not consider that this

\footnotetext{
${ }^{36}$ The scope of the applicability of the Charter is legally complex and is beyond the remit of this paper.
} 


\section{MAGNA CARTA AND ACCESS TO JUSTICE IN FAMILY PROCEEDINGS}

means that the parents bringing these cases are always likely to be particularly vulnerable (compared with detained mental health patients, or elderly care home residents, for example), or that their emotional involvement in the case will necessarily mean that they are unable to present it themselves. There is no reason to believe that such cases will be routinely legally complex."

The government's own equality impact statement accepted that the proposals would have a disproportionate impact upon women, ethnic minorities and people with disabilities. They said that it was justifiable because they are disproportionate users of the service in these areas. This led the Legal Action Group to suggest that "this would lead to an underclass of people disenfranchised from civil justice and indifferent to the rule of law". Notwithstanding these objections the government's proposals were enacted with very few changes in the Legal Aid, Sentencing and Punishment of Offenders Act 2012 (LASPO), which came into force on 1 April 2013. It removed legal aid from private law children proceedings save in those exceptional cases where domestic violence is a central feature. In such a case the alleged victim, but not the alleged perpetrator, might receive legal aid. Otherwise, at a stroke, 63 years of state funding of private family law cases was swept away. Since then the courts have been flooded with Litigants in Person. Lists of 12 cases which used to be completed in a day are now a far gone memory.

In my own decision of $M G \& J G v J F^{37}$ I set out, with as much selfrestraint as I could muster, the catalogue of cases that had arisen where the judges had commented on the gross injustice being meted out as a result of these reforms. I stated (and I do not apologise for a rather extensive quotation):

"15. Since the reforms have taken effect there have been an appreciable number of cases which have demonstrated that the blithe assumption in the consultation paper (that the parties' emotional involvement in the case will not necessarily mean that they are unable to present it themselves, and that there is no reason to believe that such cases will be routinely legally complex) is unfounded. This was entirely predictable. The cases are Kinderis $v$ Kineriene [2013] EWHC 4139 (Fam) (18 December 2013, Holman J); Re B (a child) (private law fact finding - unrepresented father) [2014] EWHC 700 (Fam) (27 January 2014, Judge Wildblood QC); $Q \vee Q$ [2014] EWFC 7 (21 May 2014, the

${ }^{37}$ [2015] EWHC 564 (Fam). 
President); $Q v Q$ (No. 2), $\operatorname{Re} B, \operatorname{Re} C$ [2014] EWFC 31 (6 August 2014, the President); $\operatorname{Re} H$ [2014] EWFC B127 (14 August 2014, Judge Hallam); Re D (A Child) [2014] EWFC 39 (31 October 2014, the President); $C D v E D$ [2014] EWFC B153 (14 November 2014, Judge Hudson); Re D (A Child) (No. 2) [2015] EWFC 2 (7 January 2015, the President); and $\operatorname{Re} K$ \& $H$ (Children: Unrepresented Father: Cross-Examination of Child) [2015] EWFC 1 (5 January 2015, Judge Bellamy). This is a formidable catalogue. Each case focussed on the gross unfairness meted out to a parent in private law proceedings by the denial of legal aid. I do not think it would be right to say that these were examples of the operation of the law of unintended consequences since, as I say, the problems were so entirely predictable."

I went on to say:

18. I need only cite a few of the judicial observations. In Kinderis $v$ Kineriene Holman $\mathrm{J}$ described the position in which the unrepresented mother in Hague proceedings found herself as follows:

"the present procedure operates in a way which is unjust, contrary to the welfare of particularly vulnerable children at a time of great upheaval in their lives, incompatible with the obligations of this state under Article 11(3) of the [B2R] regulation, and ultimately counter-productive in that it merely wastes taxpayers' funds"

In $R e H$ Judge Hallam was dealing with an unrepresented mother with speech, hearing and learning difficulties. An official of the Legal Aid Agency stated that there would be no breach of convention rights were she to remain unfunded. Judge Hallam stated "I find that statement astounding". In $R e \quad D$ the unrepresented father, who lacked capacity, had made an application to revoke a care order; the local authority had applied for a placement (for adoption) order. After heavy pressure from the President some legal aid was eventually awarded. At para 31(vi) of his first judgment the President stated:

"thus far the State has simply washed its hands of the problem, leaving the solution to the problem which the State itself has created - for the State has brought the proceedings but declined all responsibility for ensuring that the parents are able to participate 
effectively in the proceedings it has brought - to the goodwill, the charity, of the legal profession. This is, it might be thought, both unprincipled and unconscionable. Why should the State leave it to private individuals to ensure that the State is not in breach of the State's - the United Kingdom's - obligations under the Convention?" At para 21 of his second judgment he stated that "the parents can be forgiven for thinking that they are trapped in a system which is neither compassionate nor even humane".

19. In Lindner v Rawlins [2015] EWCA Civ 61 at para 34 Aikens LJ stated:

"Yet again, the court was without any legal assistance and had to spend time researching the law for itself then attempting to apply it to the relevant facts in order to arrive at the correct legal answer. To do the latter exercise meant that the court itself had to trawl through a large amount of documents in the file. All this involves an expensive use of judicial time, which is in short supply as it is. Money may have been saved from the legal aid funds, but an equal amount of expense, if not more, has been incurred in terms of the costs of judges' and court time. The result is that there is, in fact, no economy at all. Worse, this way of dealing with cases runs the risk that a correct result will not be reached because the court does not have the legal assistance of counsel that it should have and the court has no other legal assistance available to it."

20. These are powerful criticisms. The President suggested that if the Legal Aid Agency would not award legal aid to an unrepresented parent facing serious allegations then the court might have to do so from its own budget. In $R e K \& H$ that was the course proposed. The Lord Chancellor instructed leading counsel who bravely argued that the President's analysis of the existence of this power was 'plainly wrong'. Judge Bellamy disagreed and awarded representation from the court budget. The Lord Chancellor is appealing that decision. It can safely be assumed that the criticisms I have recounted have fallen on deaf ears. Based on the decisions I have cited, including no fewer than four from the President himself, it can be said that in the field of private children law the principle of individual justice has had to be sacrificed on the altar of the public debt. And based on the observation of Aikens LJ, it can reasonably be predicted that the phenomenon of the massive increase in self-representation will give rise to the 
serious risk of the court reaching incorrect, and therefore unjust, decisions."

I think that my views can be clearly gathered from what I have said in that judgment. The most acute problems arise in the situation illustrated by the cases of $Q v Q(N o .2) ; \operatorname{Re} B ; \operatorname{Re} C{ }^{38}$ and $\operatorname{Re} K \& H .{ }^{39}$ In each case the unrepresented father, who was seeking contact to his child(ren), was accused in private law proceedings of terrible sexual misconduct. For example, in $\operatorname{Re} B$ and $\operatorname{Re} C$ he was accused of raping the mother and in $R e$ $K \& H$ he was accused of sexually molesting his 17 year old stepdaughter. Obviously findings in relation to these allegations would be central to any determination of the contact issue. In the absence of legal aid the court faced the prospect of the unrepresented father crossexamining the complainant directly. That would be unthinkable in a criminal case (although not in the USA where the old right to confront your accusers is embedded in the Sixth Amendment to the Constitution), and could not happen in a public law (i.e. child protection) case where non merits based, non means tested legal aid is still afforded. The President held, obiter, that in such a circumstance the court itself could award legal representation to the accused father from its own budget and such an order was actually made in $\operatorname{Re} K \& H$, although it has very recently been overturned on appeal (22 May 2015). Lord Dyson MR held: ${ }^{40}$

"I do not consider that it is possible to interpret either section 1 of the Courts Act 2003 or section 31G(6) of Matrimonial and Family Proceedings Act 1984 as giving the court the power to require the Lord Chancellor to provide funding for legal representation in circumstances where such funding is not available under a scheme as detailed and comprehensive as that which has been set up under LASPO. The court must respect the boundaries drawn by Parliament for public funding of legal representation. In my view, the interpretation adopted by the judge is impermissible: it amounts to judicial legislation."

The Master of the Rolls held that it was perfectly acceptable for a judge to act as crossexaminer where a party is unrepresented (see paras 58 -60). However, he accepted at para 62 that a case might arise where there were complex facts or issues of expert evidence (unlike the case in hand

\footnotetext{
${ }^{38}$ [2014] EWFC 31.

${ }^{39}$ [2015] EWFC 1.

${ }^{40}$ [2015] EWCA Civ 543 [31] (Lord Dyson).
} 


\section{MAGNA CARTA AND ACCESS TO JUSTICE IN FAMILY PROCEEDINGS}

which he described as "fairly straightforward") where a breach of Articles 6 and/or 8 of the ECHR might arise were representation not to be made available; and he suggested that legislation be passed to remedy the problem. He left tantalisingly open the position were legislation not to be passed and such complexities to arise in a future case (as they surely will).

Parliamentarians have also been strongly critical of the legal aid cuts. The report of the House of Commons Justice Select Committee dated 12 March $2015^{41}$ on the impact of changes to civil legal aid under LASPO regretted the Government's failure to carry out adequate research into the legal aid system before introducing the reforms. It recorded that the Ministry of Justice "is on track to exceed spending reduction forecasts by $£ 32$ million because, following the reforms, the Legal Aid Agency is funding fewer matters than it had anticipated". It found that the exceptional cases funding scheme has not done the job Parliament intended namely "protecting access to justice for the most vulnerable people in our society". It heard ample evidence that legal aid is not reaching many of those eligible for it. It found that the rise in litigants in person constitutes at least some people who struggle to present their cases effectively, whether due to inarticulacy, poor education, lack of confidence, learning difficulties or other barriers to successful engagement with the court process. The evidence showed that the legal aid changes focused disproportionately on the crisis point of some cases and failed to appreciate the costs saving inherent in resolving disputes before they arrive at court. Its fundamental conclusion was that the faulty implementation of the legal aid changes contained in LASPO has harmed access to justice for some litigants.

Similarly critical was the report of the Parliamentary Human Rights Joint Committee dated 24 March $2015^{42}$ on the UK's compliance with the UN Convention on the Rights of the Child. It recorded a National Audit Office report on the impact of LASPO on civil legal aid changes which found a $22 \%$ rise in the number of private family law cases involving children where neither party was represented and a corresponding fall in

\footnotetext{
${ }^{41}$ House of Commons Justice Committee, 'Impact of Changes to Civil Legal Aid Under Part 1 of the Legal Aid, Sentencing and Punishment of Offenders Act 2012' HC (2014-15)

<http://www.publications.parliament.uk/pa/cm201415/cmselect/cmjust/311/311 02.htm> accessed 26 August 2015.

42 Joint Committee on Human Rights, 'the UK's Compliance with the UN Convention on the Rights of the Child' HL (2014-15); HC (2014-15) $<$ http://www.publications.parliament.uk/pa/jt201415/jtselect/jtrights/144/144.pdf $>$ accessed 26 August 2015.
} 
those where both were represented. It stated that "on the basis that cases involving litigants in person take an average of 50\% longer, it estimates an additional $£ 3$ million cost in family court cases had resulted from LASPO". It concluded: “THE GOVERNMENT'S REFORMS TO LEGAL AID HAVE BEEN A SIGNIFICANT BLACK MARK ON ITS HUMAN RIGHTS RECORD DURING THE SECOND HALF OF THIS PARLIAMENT" (Upper case in original).

Senior retired judges have also joined the chorus of criticism. In a speech to legal aid lawyers on 22 April 2015, delivered shortly before the general election on 7 May 2015, Sir Alan Moses, the former Court of Appeal judge, stated:

"No one seems to care about the plight of those who have neither the ability to protect themselves in a legal sense and cannot afford a lawyer (sic).

That [people] are deprived of the chance of legal aid seems to figure at the very bottom of concern in this election. No one thinks they are ever going to be faced with circumstances that require someone to hold their hand and safeguard them in the frightening and alienating circumstances of a court of law.

Who cares about the prisoner whose rights are abused and needs legal advice and assistance? Who cares about the immigrant who asserts they are a genuine refugee? Those who cannot afford access to the courts are often the unpopular minorities and there are no votes in helping them." 43

The retired appeal judge Sir Anthony Hooper went even further at the meeting, stating (probably unscripted and ex tempore):

\footnotetext{
${ }^{43}$ Owen Bowcott, 'senior Judge: Politicians are Ignoring Harm Caused by Cuts to Legal System' (The Guardian, 23 April 2015)

<www.theguardian.com/law/2015/apr/23/sir-alan-moses-politicians-ignoringeffects-legal-aid-cuts-election> accessed 26 August 2015.

The report says that Sir Alan said he was sorry that serving judges felt inhibited and had not spoken out about the effect of cuts to the legal system. He said: "It's a great disappointment that they have been brought up in a tradition of protecting their independence and not commenting on these things. They always say they can do something by speaking in the background but we never know what's been said. I'm confident that the judges are very concerned about cuts to legal aid and that it's very inefficient."
} 


\section{MAGNA CARTA AND ACCESS TO JUSTICE IN FAMILY PROCEEDINGS}

"I'm completely depressed. I started out in the legal profession 30odd years ago when we had as Rolls-Royce a system as you possibly could have. This has been destroyed gradually and then quickly over the past few years. Whatever we have said it's not made any difference at all. If the Conservatives come back into power, it's revolution time. We have to stop helping them and stop working. The Bar Council are not going to do anything. The Law Society is not going to do anything. The judges are not going to do anything. Unless you [lawyers] are prepared to withdraw your labour you have no hope. If the Tories get back in, they haven't even started on us."

Sir Alan and Sir Anthony, along with a further 136 prominent peers, lawyers and doctors working in the civil and criminal justice systems signed an open letter to the Guardian on 1 May 2015 calling on the incoming government to restore legal aid to prevent "widespread miscarriages of justice". ${ }^{44}$ In it they pointed out that in 2010, annual expenditure for the civil and criminal justice system stood at approximately £2bn per annum, which equates to the cost of running the NHS for a fortnight. Spending was falling and was not spiralling out of control. Now the level of spending is down to approximately $£ 1.5 \mathrm{bn}$ per annum. The effect of the cuts is reflected in "eye-watering statistics". From 2012-13 to 2013-14, funded debt cases fell from 81,792 to 2,423; in clinical negligence from 2,859 to 114 ; in employment law from 16,154 to six. Funding in family law cases dropped by $60 \%$, causing a predicted rise in unrepresented defendants, a trend now also starting to be seen in the criminal courts.

They went on to say:

"What the figures do not convey is the sheer human misery of being unable to get legal advice. ... With cuts and debilitating

\footnotetext{
${ }^{44}$ Other signatories included retired Appeal Court judge Sir Stephen Sedley, visiting professor at Oxford University; Lord Ramsbotham, the army general who became HM chief inspector of prisons; Lord Carlile QC, the former Liberal Democrat MP and one-time independent reviewer of terrorist legislation; Baroness Ruth Lister, professor of social policy at Loughborough University; Frances Crook, chief executive of the Howard League for Penal Reform; Shami Chakrabarti, director of Liberty; Baroness Helena Kennedy QC; Sir Geoffrey Bindman QC; and Michael Mansfield QC.

See 'Legal Aid Cuts Threaten Our Very Democracy' (The Guardian, 1 May 2015) <www.theguardian.com/law/2015/may/01/legal-aid-cuts-threaten-verydemocracy> accessed 26 August 2015.
} 
restructuring comes the spectre of advice deserts, widespread miscarriages of justice, hundreds of thousands denied redress and the draining of the talent pool of future lawyers and judges as young people increasingly choose a career away from civil and criminal law. ... Politicians speak about access to justice as an optional extra that we simply cannot afford. But the introduction of legal aid, replacing the ad hoc 'poor law' scheme of the 1920s and 1930s, came during a period of true austerity in the wake of the Second World War. Access to justice is more than just a public good which we can choose to fund generously when we are told our economic fortunes allow. Without access to justice for all, inequalities take on a more dangerous edge which threatens the legitimacy of not just the justice system but our democracy."

They called on the new government to restore legal help to the many currently without redress and to establish a Royal Commission to investigate the current crisis regarding the diminution of access to justice.

Even allowing for the need to make cuts in order to reduce the fiscal deficit I do not accept that in the critically important area of private family law it has been necessary to sacrifice individual justice on the altar of the public debt, at least not to the extent that has happened. It is not clear to me why this particular pillar of the welfare state has had to fall. I have yet to hear a convincing riposte to Dr Cohn's argument cited above, which has, until recently, been part of the bedrock of the post-war settlement. The prediction of the Legal Action Group is slowly but surely being fulfilled. Is this the legacy that we wish to leave future generations? Sadly it looks as though that will be so, and there will be no respite from further cuts. Apart from the Greens no party included a reversal or mitigation of the legal aid cuts in its election manifesto. The unexpected victory and attainment of an absolute majority by the Conservatives on 7 May 2015 surely means that there is no prospect of reversal of these cuts, and that more are in prospect.

Thus far my address has been exclusively Anglo-centric, for which I apologise. I gather that things here in Australia are no better. I am indebted to Dr David Neal SC and David Hillard who have educated me on the position here, but I would not presume to dilate on it, let alone to criticise it. You know the position far better than I do.

It is perhaps an irony that for many years Australian legal aid campaigners held up the UK legal aid system as a model. From inception it was a system which provided aid across the board in criminal, family and civil matters at rates which made it economically viable for lawyers to work on legally aided cases. As I have shown, the UK government, until 


\section{MAGNA CARTA AND ACCESS TO JUSTICE IN FAMILY PROCEEDINGS}

the arrival of the coalition in 2010 , had been committed to providing levels of funding which reflected a genuine commitment to the principle of equality before the law. I am told that the modern era of legal aid in Australia - which dates from the Whitlam government of 1972 - has never seen either the breadth of coverage or the level of funding to match the UK legal aid system. ${ }^{45}$ The first decade of the 2000 s saw legal aid commissions progressively reduce grants of legal aid in order to stay within their tightly constrained budgets. They have increasingly imposed means tests, merits tests, quotas, and have taken legal areas out of scope. David Hillard tells me that now legal aid funding is $\$ 20 \mathrm{~m}$ p.a. less than it was in $1997 .{ }^{46}$ I gather that in five of the eight States and Territories, the means test for a grant of legal aid excludes some people who fall below the commonly accepted "Henderson Poverty Line". ${ }^{47}$ I gather that in this state the income limit is $52.4 \%$ of the minimum weekly wage. I gather that only $8 \%$ of households would qualify for contribution free legal aid and that only a further $3 \%$ would qualify for a grant with a contribution. Based on research done by PricewaterhouseCoopers in 2009, total Australian government spending on legal aid commissions came to $\$ 28$ per capita. By contrast, the UK government spent $\$ 86$ on legal aid. ${ }^{48}$ By 2012 , the UK figure had dropped back to $\$ 60$ per capita. ${ }^{49}$ I gather that in Victoria a parent in a private family law residence and contact dispute will not be granted legal aid for representation unless the other party has a lawyer. That is bad, but at least it is an improvement on what is happening now in England and Wales. I gather that children under 10 will no longer have someone to represent them in child protection cases even when the court says they should. That is even worse than the position in England and Wales. ${ }^{50}$ I gather that a recent agreement thrashed out in Canberra concerning the funding of community legal centres will impose further

\footnotetext{
${ }^{45}$ David Neal, 'Law and Power: Livin' in the '70s' (2013) 29 Law in Context 99.

46 This figure has not been adjusted for inflation. You have \$20m less in 1997 dollars.

47 Pricewaterhouse Coopers, Legal Aid Funding: Current Challenges and the Opportunities of Cooperative Federalism (2009) 36.

48 ibid 59-60.

49 European Commission for the Efficiency of Justice (CEPEJ), 'Report on European Judicial Systems - Edition 2014 (2012 data): Efficiency and Quality of Justice'

<http://www.coe.int./t/dghl/cooperation/cepej/evaluation/2014/rapport_2014_en. pdf $>$ accessed 26 August 2015, 46.

50 'Legal Aid Matters' (Law Institute Victoria) <http://www.liv.asn.au/ForLawyers/Submissions-and-LIV-projects/Legal-Aid-Matters> accessed 26 August 2015 .
} 
swinging cuts: it will fall from $\$ 42 \mathrm{~m}$ annually to $\$ 30 \mathrm{~m}$. A depressing harbinger indeed.

Although Australia has not yet suffered the full extent of the dramatic cuts imposed in 2013 in the UK, the writing is clearly on the wall here. The declining commitment of governments in both countries to genuine equality before the law and to the cluster of rule of law concepts - of which Magna Carta forms a significant part - should put a brake on meretricious rhetoric and produce calls for fidelity to the ideals which they both claim.

Let me end with the words of Sir Alan Moses in the speech from which I have already quoted:

"so let me suggest a measurement for the success of our society and democracy, so happily ignored by those who seek majority support. It is how we deal with and protect our unpopular minorities. Democracy even during an election is not about the will of the majority but about how the voiceless minority - those who are unprotected and without legal assistance - are protected against power: the power of the majority and the power of those who govern us." 